\title{
TRADITIONS AND INNOVATIONS IN THE DEVELOPMENT OF THE HIGHER SCHOOL IN THE TERRITORY OF UKRAINE: EUROPEAN DISCOURSE
}

\section{Larysa Korzh-Usenko}

\section{INTRODUCTION}

Eurointegration and globalization processes of modernity encourage revealing the importance of external factors (first of all, intercultural interactions) as well as internal logic of higher education development in a certain country, aimed at ensuring high educational standards and preservation of national-cultural identity. As a civilization crossroads between the "humanist West" and the "Byzantine East"1, Ukraine is situated geopolitically and mentally at the intersection of various cultures and civilizations, creatively interpreting impulses from the outside. In the reforming process of the higher educational system, preserving humanistic European values, creating an open cultural and intellectual space, harmonizing academic traditions and innovations, embodying real university autonomy, realizing academic freedoms, achieving high education standards are of exceptional relevance.

In the study the ideas of the university's mission and function developers were considered (M. Weber, M. Heidegger, V. Humboldt, J. Derrida, P. Morav, J. Newman, H. Ortega-i-Gasset, J. Pelikan, F. Schleiermacher, K. Jaspers). Among the fundamental works should be noted the 4-volume edition "History of Universities in Europe". Significant contribution to the coverage of the historical experience of "intellectual tourism" of Ukrainians in Europe was made by V. Horskyi, S. Grachotti, S. Kurbatov, V. Litvinov, V. Mykytas, D. Nalyvaiko, V. Nychyk, H. Nudha, O. Pakhlovska, Yu. Stratii, M. Shalat. The activities of the Ostroh and Kyiv-Mohyla Academies were revealed in the writings of Y. Isaievych, T. Ketra, I. Krypiakevych, V. Mankivskyi, Y. Mytsyk, O. Pritsak, Z. Khyzhniak, M. Yaremenko. History of Higher Education in the XIX - beginning of the XX cen. - N. Demianenko, O. Drach, L. Zelenska, L. Levytska, V. Kachmar, S. Kessou, M. Krykun, H. Kosinova, S. Kulish, Y. Mokliak, S. Pakholkiv, S. Posokhov, H. Hausman, T. Udovitska, T. Maurer and others. However, contemporary historiography lacks research that presents

\footnotetext{
${ }^{1}$ Pakhlovska, O. (1990). Ukrainian-Italian literary connections of the XV-XX centuries. Kyiv.
} 
historical transformation of the ideal of a highly educated person, mission and dominant model of higher education in Ukraine, taking into account European theory and practice.

\section{Higher education origins in the territories of Ukraine and European cultural and educational impacts}

The origin of the first sprouts of classical education in the territory of modern Ukraine is connected with the spread of ancient civilization and culture in the Greek cities of the Northern Black Sea coast. The individuals who acquired knowledge from well-known philosophers and rhetors (in the local poleis, in the metropolis - in Athens or in Alexandria) were highly educated ${ }^{2}$. According to Herodotus, interest in the study of "Athenian sciences" was shown not only by the citizens of the poleis, but also by the representatives of the Scythian nobility, however, traitors of the native faith and traditions who were tempted to "Hellenization" were executed with a terrible death. A striking example is the philosopher Anaharhis, one of the canonical "seven wise men".

The dominance of the Greek-Byzantine "cultural code" as a result of the Christianization of Kyivan Rus had strategic implication for the selfaffirmation of the state in the community of European nations. Having fallen into the orbit of the spiritual influence of Byzantium - the most educated country, the guardian of the ancient heritage, Rus participated in the active assimilation of classical cultural standards. The sources ${ }^{3}$ indicate that orientation towards Constantinople prompted the Kyivan princes to impress the world recognition of high state status of education. According to the ancient chronicles, in 988 Prince Volodymyr Sviatoslavyh founded a "palace" school in Kyiv - a closed elite institution. Organization of the "palace" schools in Rus could have been influenced by the model Pandidakterion - a higher school in Constantinople, similar to the Roman Athenaeus, in which were educated enlighteners Cyril and Methodius, and the first even taught philosophy. Training of the highly educated civil servants and higher clergy was carried out on the basis of mastering the "seven free arts", singing, a series of philosophical and theological disciplines in schools of a "higher type" (secular and religious) or through

${ }^{2}$ Skrzhinska, M. (2013). Education in the process of formation of antique states in the territory of Ukraine (VI-IV centuries BC). In V. Smolii (Ed.), Ukraine in Central-Eastern Europe, vol. 12-13, pp. 15-31. Kyiv.

${ }^{3}$ Sichinskyi, V. (1946). Strangers about Ukraine. The choice from the descriptions of travels around Ukraine and other scriptures of strangers about Ukraine for ten centuries. Avgsburg. 
self-education ${ }^{4}$. In the "Tale of the Past Years", young men who study philosophy and seek to reach the peak of wisdom, collecting everywhere the most valuable, are compared with busy bees. If in Kyivan Rus attention was paid to Greek and Old Slavonic languages, then in Galician Rus active contacts with Vatican and Western Europe led to an in-depth study of Latin and German.

Due to the rapid political, economic, cultural and educational uplift, Kyiv was called in medieval sources "the pearl of the world", "the second Constantinople", "the new Jerusalem", the capital of one of the largest states. The yard and the academy of Yaroslav the Wise with a scriptorium and a huge library in the St. Sofia cathedral became the azimuth for many princes from Western Europe and future monarchs, and the successful "marriage diplomacy" contributed to strengthening the position of Kyivan Rus in the international arena ${ }^{5}$. The cult of books and scholarship dominated in the families of such Russian princes as Yaroslav the Wise, Vsevolod, Volodymyr Monomakh - the author of "Instructions to his children", which has a significant pedagogical potential. The ideal of a highly educated person assumed respect for Christian virtues, active living position and optimism, awareness of "Athenian wisdom", foreign languages, physical and aesthetic development, poetic talent as a symbol of the perfection of intelligence. Wisdom, charity and hunting skill distinguished the daughter of Yaroslav the Wise Anna (Agnes) - the queen of France, the wife of Henry I. Princess Konegunda (Kunguta) of Galicia - the wife of the Czech king Przemysl Otakar II - became the first Czech poet. Feodulia (Euphrosinia), the daughter of Prince Mikhailo Vsevolodovych, a well-known doctor, a connoisseur of grammar, rhetoric and philosophy, "knew all the books of Vergil and Vitus, and also the books of Aesculapius, Galenus, Aristotel, Homer, and Plato" and her sister Maria wrote poetry and co-authored the "Life of Prince Mikhailo of Chernihiv"6.

At that time, the practice of deepening higher education in well-known foreign centers, first of all in Constantinople and Athos, was initiated. From the XIV century, the center of gravity for curious intellectuals was Italy - the center of Roman antiquity, the "cradle" of the universities and the generator of Renaissance ideas. A bright star in the galaxy of humanists is the talented scientist, honorary citizen of Bologna Yurii Kotermak (known as Yurii Drohobych, Yurii from Lviv, who on Galicia land, Giorgio from Rus),

\footnotetext{
${ }^{4}$ Babishin, S. (1973). School and education of ancient Rus. Kyiv: Higher school.

${ }^{5}$ Ibid.

${ }^{6}$ Korzh-Usenko, L. (2017). Genesis of conceptual approaches to organization of the educational process in the higher school of Ukraine. Scientific notes. Series: Pedagogical Sciences, vol. 156, 80-86.
} 
initiator and editor of the first Cyrillic books. The classic of the world music is composer Maxim Berezovskyi, who had studied in Italy for ten years. The name of the maestro, the academician of the Bologna Philharmonic Academy, was stamped on the marble board of this institution, along with W. Mozart ${ }^{7}$. Very significant was the representation of students from Ukraine at the University of Padua: only in the XVII century there were about 2500 people $^{8}$. Among the students of Padua, who were influenced by the spirit of free-thinking, were the future rector of the Kyiv-Mohyla Academy Ioasaph Krokovskyi and Ukrainian Hetman Ivan Mazepa. A rhetor ("Ukrainian Demosthenes" and "modern Cicero"), a polemicist, a historian Stanislav Orykhovskyi-Roksolan, who himself studied at eight universities, directed his talented fellow countrymen to Padua and other well-known centers, because who seeks to become highly educated, has "to direct his thought to Rome, to Athens, to Jerusalem and seek everywhere in the world". Recognizing patriotism as a supreme virtue, S. Orykhovskyi considered himself the son of the "Ukrainian people of the Polish state" and proved the inclination of his compatriots to education from the times of Kyivan Rus ${ }^{9}$.

Among the boys who learned from the sources of wisdom in Rome - the future rectors of Ostroh and Kyiv-Mohyla academies - were Greek Cyril Lucaris (who also studied in Padua) and Theophanes Prokopovych. The student of Sorbonne was the Kiev Metropolitan, the founder of the KyivMohyla Academy Petro Mohyla, and the student of Cambridge - the future rector of this Academy Innocent Giselle. The famous Ukrainian writer and philosopher Hryhorii Skovoroda received Italian education ${ }^{10}$. The desire for the encyclopedic character of knowledge turned some adherents of science into "eternal students". At the Jagiellonian University until the middle of the XVII century about 2,000 Ukrainian students were educated and many professors from Ukraine worked. Ukrainians actively studied in France, the Czech Republic, Austria, Hungary, the Netherlands, Sweden, Switzerland, England and Spain. Comparative analysis shows that German universities Wittenberg, Heidelberg, Gottingen, Leipzig, Strasbourg - became popular with the development of natural science studies while in the Italian

\footnotetext{
${ }^{7}$ Pakhlovska, O. (1990). Ukrainian-Italian literary connections of the XV-XX centuries. Kyiv.

${ }^{8}$ Nychyk, V., Litvinov, V., Stratii, Yu. (1991). Humanistic and Reformation Ideas in Ukraine (XVI-early XVII century). Kyiv.

${ }^{9}$ Stanislav Orikhovskyi: works (2004). Kyiv: Dnipro.

${ }^{10}$ Pakhlovska, O. (1990). Ukrainian-Italian literary connections of the XV-XX centuries. Kyiv.
} 
universities flourished humanitarian and legal disciplines, astronomy, and medicine.

It was the humanists and their students who led the new system of values of Western European society, which included the ideas of the emancipation of the individual, the rise of man and the recognition of his right to earthly happiness, democracy, socially useful activity, service to the homeland, development of native culture. The famous Italian humanist of the XV century Filip Buonaccorsi Kallimach became the leader of the Renaissance cell in the Dunaiev near Lviv and one of the apologists of the humanist movement in the Polish-Lithuanian state. The Italian historian Bisaccioni Maiolino called the Ukrainians "the noblest knights" and "skilful farmers", with a clear desire for knowledge even among ordinary people ${ }^{11}$. Foreign travelers and diplomats solidified in recognition of the "civilization and education of Ukrainians" (P. Alepskyi, G. L. de Boplan, F. Weber, P. Gordon, E. Clark, D. Krman， H. Manstein，D. Marshall， J.-B. Scherer, Y. Just), arguing that the Cossacks were "educated people aware of science and law, and good connoisseurs of rhetoric, logic, and philosophy". According to the optimistic prognosis of the famous German philosopher and ethnographer Johann Herder, Ukraine once "will become a new Hellas for the world"12. In the opinion of the Italian professor Santa Grachetti, during the Baroque era, Ukraine demonstrated its "pan-European vocation", and thanks to the "cult of freedom" joined the "universal fund of Europe" and became its popularist in the Slavic world ${ }^{13}$. Actually, at the mental level, Ukraine had never been separated from the European civilization (unlike the Moscow state).

The openness of the educational space to the acquisition of positive experience, interconfessional competition in meeting spiritual needs, the spread of the Protestant and Jesuit humanistic collegia formed on the basis of the pan-European program of enlightened piety and filtration of the classical heritage from the standpoint of Christian ethics, stimulated the search by Ukrainian intellectuals of their own model of higher education. Thanks to the synthesis of the concept of the "Tree Languages Lyceum" of Erasmus of Rotterdam, the experience of the organization of the school of Prince Jerzy

11 Nychyk, V. (2002). From the Renaissance Italy to the Reformation Germany. In V.S. Horskyi (Ed.), Religious-Philosophic thought in Kyiv-Mohyla Academy: European Context, Kyiv: Academy.

${ }^{12}$ Sichinskyi, V. (1946). Strangers about Ukraine. The choice from the descriptions of travels around Ukraine and other scriptures of strangers about Ukraine for ten centuries. Avgsburg.

${ }_{13}$ Grachotti, S. (1993). The heritage of the Renaissance in the Ukrainian Baroque. Ukrainian Baroque: Materials of the I Congress of the International Association of Ukrainists, (27 August - 3 September 1990 r.), Kyiv, pp. 3-11. 
Pyas in Brzeg and the Italian academies with the national tradition in Ostroh was established an educational and scientific complex, which combined an education institution, a circle of scientists, a printing house, a library, a church, and a hospital. The patron of the cell was the magnate and philanthropist Constantine-Vasyl Ostrozkyi, the son of the Great Hetman of Lithuania, whose genus came from the princes of Kiev, was able to draw a cohort of scholars (first of all, from the Greek college of St. Athanasius in Rome and the University of Padua, where many representatives of the Ostrozkyi family were educated) ${ }^{14}$. A significant donation to the academy and hospital was carried out by the niece of the prince Elizabeth-Halshka Ostrozka. As prince Krzysztof Radziwil testified, K.-V. Ostrozskyi "builds an academy with great piety and almost royal scope" 15 .

The innovative character of the "Ostroh Atene" was manifested in the appeal to the legacy of Kyivan Rus as "domestic antiquity" and the sacralization of the native language in its Old Slavonic version, which was positioned as classical. Since the Slavic-Greek-Latin Ostroh Collegeacademy (1576-1636) carried out training of the Orthodox intellectuals with a broad worldview, capable of controversy with ideological opponents, Jesuits were a dangerous center of "schism". In addition to "free arts", philosophical and theological sciences and medicine were taught here. The peculiarity of the academy was the combination of its Orthodox orientation with tolerance and ideological diversity, enhanced study of native and classical languages, as well as Hebrew and Polish (state). The leaders of the Venetian-Padua sample of education were teachers and members of the scientific circle Havrylo Dorofeiovych, Cyril Lucaris, Cyprian, Jan Liatosh, Nykyfor Parashes-Kantakuzin. Having finished their study in Ostroh, the most talented students were preparing for teaching, deepening their education in Italian centers as scholarship holders of the prince. The result of the fruitful work of the circle of Ostroh intellectuals was preparation of the educational literature, translation into Slavic and the publication of the fundamental "Ostroh Bible". As a supporter of the inter-confessional dialogue, Ostrozkyi turned for help in building the institution to the Pope of Rome and Orthodox hierarchs; Ecumenical ideas of the prince were shared by the rector of the institution, Cyril Lucaris, the future Ecumenical Patriarch. In 1602, at the request of the Alexandrian Patriarchs in Greece, a branch of the Ostroh cell was opened, on which were relied a lot of hopes in

${ }^{14}$ Paton, B., Smolii, V. (Eds.) (2003). History of Ukrainian culture: in 5 vol. Vol. 3: Ukrainian culture of the second half of XVII-XVIII centuries. Kyiv.

${ }^{15}$ Kempa, T. (2009). Kostiantyn Vasyl Ostrozkyi: Voievoda of Kyiv and marshals of Volyn land. Khmelnytskyi. 
connection with the collapse of Constantinople ${ }^{16}$. The mission of restoration on the Ukrainian lands of its own metropolitan power, actualized by K.-V. Ostrozkyi, with the aim of the spiritual revival of the greatness of Rus, managed to realize the former student of Ostroh, the Ukrainian hetman, Petro Sahaidachnyi (1621). It us symbolic, that the metropolitan of Kiev, Galicia and all Rus became a student of Ostroh Academy, rector of Lviv and Kyiv fraternal schools Iov Boretskyi.

Although K. Ostrozkyi's persistent attempts to give the college-academy a legal status equal to the university were not successful because of the resistance of the Jesuits and the death of the founder, but the students of the institution became representatives and patrons of the native education and culture, the founders and teachers of the brotherhood schools directed at Ostroh standards. The origins of the Orthodox universities with their native language of instruction and the democratic composition of students were brotherhood schools (Lviv, Lutsk, and Vilno), whose high level of teaching was confirmed by the privileges of the Orthodox patriarchs and the Polish king $^{17}$.

However, as a result of the intensification of the Jesuit offensive, the students of the brotherhood schools of Ostroh cell concentrated their efforts in the city of Kyiv, the historic capital of Ukraine-Rus. Just in the cradle of the "Ruthenian antiquity" in the atmosphere of renaissance of the greatness of the Kyiv shrines, with the support of philanthropists (Halshka Hulevychivna, Kyiv Metropolitans, Ukrainian Hetmans), a well-known Kyiv-Mohyla Academy originated. In the basis of the Kyiv collegium (academy) Petro Mohyla laid the Catholic model of the French Sorbonne, whose student he was, while also adapting the newly created institution to the values and urgent needs of Ukrainian society. Instead, O. Pakhliovska points out the similarity of the mentioned institution to Zamoisk Academy, oriented towards the model of the University of Padua, which was an important center of the Ukrainian Renaissance culture ${ }^{18}$. In order to update the genetic continuity of the authentic educational traditions in the chronicle "Rusy's History" it is noted that Hetman Sahaidachnyi together with Petro Mohyla revived the ancient Kyiv Academy, which was laid after the introduction of Christianity in Rus.

\footnotetext{
${ }^{16}$ Pasichnyk, I. (Ed.) (2011). Ostroh Academy of the XVI-XVII centuries: Encyclopedia. Ostroh.

${ }^{17}$ Paton, B., Smolii, V. (Eds.) (2003). History of Ukrainian culture: in 5 vol. Vol. 3: Ukrainian culture of the second half of XVII-XVIII centuries. Kyiv.

${ }^{18}$ Pakhlovska, O. (1990). Ukrainian-Italian literary connections of the XV-XX centuries. Kyiv.
} 
The Academy carefully guarded its own traditional rights and like the Krakow University, recognized by the Polish king in 1658: academic autonomy, the jurisdiction of the own court, the election of teachers and rector, the democratic (omnipresent) nature of education, the activities of academic congregations, the possibility of challenging students' abusive teachers, etc. For foreigners of the XVII-XVIII centuries, the Kyiv Academy was "a true Orthodox University with a good reputation", a source of highlyeducated intellectuals in Eastern Europe ${ }^{19}$. An innovative Mohyla model of the Orthodox University was implemented in the branches and colonies of the Kiev metropolitan power: Vinnytsia, Hoshcha, Yassy, Moscow, Wallachia, Serbia, Orthodox collegia of Ukraine. An evidence of the international significance of the institution's activities is training of Ukrainians, Belarusians, Russians, Moldovans, Serbs, Bosnians, Montenegrins, Bulgarians, Greeks, and Italians.

Special attention in the academic environment was paid to the antique heritage, the works of Italian, German, Swiss humanists, reformers. Despite careful study of the system of Th. Aquinas, ancient philosophy at the Academy was taught not in the medieval (Thomistic), but in the Renaissance-humanistic interpretation (Pahl'ovs'ka (1990). The professors of the Academy propagated the ideas of such Italian Renaissance thinkers. Of particular interest were the works of R. Descartes, F. Bacon, A. Vesalius, and $\mathrm{N}$. Machiavelli, which were aimed at learning nature and society through intelligence, experience and experiments. Significant pedagogical potential had the ideas of the French encyclopedists (A. Voltaire, D. Diderot, Ch. Montesquieu, J.-J. Rousseau), the representatives of the English education (J. Locke, T. More, Anselm of Canterbury) (Korž-Usenko, Martinenko (2013), and especially - of the Dutch humanist Erasmus of Rotterdam and the Czech pedagogue J. A. Comenius, who considered qualitative education as a guarantee of Ukraine's national independence.

At the end of the XVIII century the traditional trivium and quadrivium at the Academy were complemented by classes of painting, history and geography, home and village economics, medicine. The implementation of the individual learning trajectory provided the flexibility and variability of the content of academic education. Most students were exceptionally interested in rhetoric. The philological training of students was substantial in addition to Greek, Latin, Slavic, Hebrew, Polish they studied French, German, and possibly some Oriental languages. Gradually, the tendency to

${ }^{19}$ Sichinskyi, V. (1946). Strangers about Ukraine. The choice from the descriptions of travels around Ukraine and other scriptures of strangers about Ukraine for ten centuries. Avgsburg. 
increase the intellectual saturation of educational courses (in classical and new languages, mathematics, psychology, ethics, "higher sciences", medicine, natural science), provision of an aesthetic component of students' training (musical, drawing, theater classes) had intensified. The creative approach to teaching assumed the use of the elements of dramatization, game, dialogue, problem technology, aimed at the development of autonomy of students' thinking. Of particular importance were developing students' polemical skills. Priority was given to positive methods of stimulating academic integrity: encouragement (praise, gratitude, public honor, guidance, promise, and reward), competitiveness, and mutual control. The differentiated approach manifested itself in supporting gifted youth (practice of auditing, honorary positions in the system of self-government, opening of the perspectives of teaching activity, travel abroad for studying, recommendation for work); carrying out additional classes with disadvantaged students and their mastering of certain crafts (painting, icon painting, pharmacy, printing skills). In a number of virtues, which were cultivated in students, a sense of personal dignity and originality of thought were especially appreciated. For the development of creative abilities, the exercises with "national interpretation" of classical masterpieces were often practiced. Thus, as a result of the "turning" of Vergil's masterpieces "Ekloge" and "Bucolica", appeared the poems of Ivan Lobysevych "Vergi's shepherds, in the Ukrainian coats dressed", Ivan Kotliarevskyi's "Aeneid", with which the formation of the new literary Ukrainian language is associated.

As a real national shrine of the Ukrainian Cossack state, the KyivMohyla Academy ("Kyiv Parnassus", "Our Sorbonne", "Ruthenian Paris") performed a mission of forming the intellectual elite, preserving the religious-national identity, and creating an open cultural and intellectual space $^{20}$. The usual practice for representatives of elite Cossack families (Razumovskyi, Orlyk, Poletyk, Khmelnytskyi, Samoilovych, Skoropadskyi) and the best students who intended to become teachers was deepening abroad of knowledge acquired at the Academy. Signs of European education were nobility, erudition, perfect knowledge of foreign languages, bibliophilia, charity and philanthropy. For example, Ukrainian hetmans I. Mazepa and K. Razumovskyi, who received education at several universities, provided a significant moral and material support for the KyivMohyla Academy. In general, the existence of its own state and the church

${ }^{20}$ Pritsak, O., Sevcenko, I. (Eds.) (1985). The Kiev Mohyla Academy (Commemorating the 350th Anniversary of Its Founding, 1632-1982), Harvard Ukrainian Studies, vol. VIII, n. 1/2, Cambridge, MA. 
(Kyiv metropole), democratic traditions (Magdeburg law, electiveness of officials and teachers), the patronitarian policy of Ukrainian hetmans contributed to the development of education. At the same time, a number of projects on the opening of modern Ukrainian universities and the reform of the current academy were blocked by the Russian government after the abolition of Hetmanate in Ukraine hetman.

With the help of the method of diachronic analysis it has been established that: if in the Middle Ages the only source of truth was considered God, and man was positioned as the object of Divine revelation, then in the New time, the person began to be perceived as the subject of scientific knowledge. The Kyiv Mohyla Academy fulfilled the role of a creative laboratory for the formation of the "man of Baroque", whose critical mind overcame the limitations of theocracy, contributing to the birth of secular mentality. The bright representatives of the Ukrainian Baroque culture were composers D. Bortnianskyi and A. Vedel, philosopher H. Skovoroda, architect I. Hryhorovych-Barskyi, traveler V. HryhorovychBarskyi. Oriented to antiquities and medieval theology, scholastic education was gradually substituted by the Leibniz-Wolffian system. However, at the end of the XVIII century, under the pressure from the Russian government, the Ukrainian language was superseded, the right to academic autonomy and self-government was abolished, censorship was introduced, which led to the closure of the institution, and later to the creation of a spiritual academy on its basis. Within the typology of university education at the dawn of the New Age in the fundamental publication "History of the University in Europe", Kyiv Academy was represented as a true university - based on its similarity to Jesuit higher schools, which supported theological and philosophical departments.

A typical Jesuit university of the pre-classical type was the University of Lviv (1666), closed after the abolition of the Order. On its basis, in 1784, the Austrian Prince Joseph opened in Lviv the classical university, intended primarily for the needs of Ukrainians, functioned the Ukrainian InstituteStudium Ruthenum (1787) and a number of Ukrainian chairs ${ }^{21}$. At the same time, in the Russian Empire the influential Polish and Russian circles, trying to monopolize the "intellectual Olympus" for "domination over the souls of Ukrainians", prevented creation of modern universities by placing a bet on the lyceum - the sui generis "ivory towers" (Kremenets, Nizhyn, Odesa), equalized in rights with universities; they had a number of privileges that

${ }^{21}$ Vakarchuk, I. (Ed.) (2011). Encyclopedia. Lviv Ivan Franko National University: in 2 vol. Vol. 1: A-K. Lviv. 
provided elite education to immigrants from aristocratic families ${ }^{22}$. During the ten-year course of study, the young gentry was taught to be a true European through the mastery of foreign languages, secular manners, and jurisprudence.

\section{Modern accents in the development of higher education in the territory of Ukraine}

It should be noted that with the incorporation of the Ukrainian lands into the Austrian and Russian empires, the purpose of the universities from the point of view of the state was seen in imposing imperial values and the faithful service of the ruling dynasty. Choosing among different contenders for the status of a university city, the Russian government was guided primarily by the criterion of loyalty to the current power of the local population. Kharkiv (1804), Kyiv (1834), Novorossiisk universities (1865) were opened by autocracy as institutions for the training of state officials and the strongholds of russification. Moreover, Kharkiv University is the first and the only one in the Russian Empire, created in accordance with the "bottom-up" initiative and on the basis of private donations, with the hope of taking into account the interests of the local community.

The diachronic analysis shows that if in the first half of the XIX century, the classical content of higher education (emphasis on knowledge of Latin and Greek, ancient philosophy, history, art, rhythmics and metristics) predominated at universities in combination with compulsory study of theology, then over time, under the pressure of the public, the content component was developed by taking into account the achievements of world science and the needs of a particular region (new languages, modern philosophy, natural sciences, political economy, jurisprudence, sociology, vocational and psychological-pedagogical disciplines).

The method of the retrospective analysis helped reveal a number of factors that had influenced the efficiency of the educational process at the universities of the Russian Empire in the XIX and early XX centuries: the inconsistency of government policy in higher education; displacement of the personalityoriented paradigm, characteristic for European civilization, by the traditions of state domination; restriction of the social and legal status of participants in the educational process, repression against "unreliable" teachers and students; violation of the principle of free development of scientific knowledge; strengthening of the religious-ideological direction of education and upbringing; temporary prohibition during the reaction period of a number of training courses and areas of research (philosophy, psychology, pedagogy,

\footnotetext{
${ }^{22}$ Bovua, D. (2007). Russian government and Polish gentry in Ukraine (1793-1830). Lviv.
} 
logic, natural and European law, political economy, Ukrainian studies disciplines); restriction of scientific-educational cooperation with Europe; narrowing of the variable component of the content of education; excessive regulation, unification, russification; strict censorship of lecture courses and educational literature; the use of positive European experience; the position of academic councils in solving academic problems; professional-pedagogical skills, authority and personal example of teachers; persistence of students in the struggle for their own academic needs.

At the beginning of the $\mathrm{XX}$ century, in the Ukrainian lands of the Russian and Austro-Hungarian empires, along with the classical state universities that functioned according to the model of Berlin and Vienna universities, there were about 30 branch universities (oriented in particular to the standards of the Paris Polytechnic with a mobile multi-profile structure and Italian Agricultural Higher Schools). However, despite the unofficial status of Ukraine as a breadbasket in Europe, the Russian government did not respond to persistent requests from the public on the creation of higher schools of agrarian profile in its territory, as well as national universities, which most Ukrainians, mostly peasants, needed ${ }^{23}$. At the same time, according to a comparative analysis, higher national schools, designed for representatives of different nationalities, successfully operated in the neighboring Austro-Hungarian Empire.

In conditions of the scientific-technological revolution, formation of market relations, intensification of the processes of nation-building, the progressive professorship and the public developed an alternative anthropological model of higher education, subordinated to the goal of selfdevelopment of the creative person, the ideas of academic freedom, the deformalization of the pedagogical process, auto-dydacticism, "postuniversity" education, were tested in free higher schools. By the high level of organization of the educational process Kyiv Commercial Institute, Kyiv Polytechnic Institute, the Higher women's courses in Kyiv, Kharkiv, Odesa, Kyiv Froebel Institute were distinguished. The criteria for the quality of higher education had become the increased academic tone and the level of students' mastery of methodology, development of critical thinking, the ability of students to scientific creativity. Gradually, the knowledge-based approach to the organization of the educational process changed to personality-oriented, and the reproductive nature of the texts of lectures and textbooks - to the productive, which facilitated the flexibility of the curriculum, the expansion of sources of information, the introduction of

\footnotetext{
${ }^{23}$ State Archive of Kharkiv Region. Fund 45, Description 3, Case 3135.
} 
active forms of education. Instead of review or factual lectures, priority was given to problem and methodological ones.

The introduction of individual education plans, improvement of the microclimate in the student-teaching environment contributed to increasing of the motivation for academic work and the establishment of cooperation between the participants in the educational process. Thus, the development of the innovative potential of the Kiev Commercial Institute was provided by the qualified teaching staff, an in-depth specialization in the training of specialists, extensive use of excursions and practical forms of training, a rational organization of international internships and industrial practices. Substantial foreign language training was provided through learning of new European languages (English, German, French, Italian) and more "exotic" eastern (Japanese, Chinese, Turkish, Arabic), while universities paid attention to "dead" languages.

In order to familiarize with the last word of science and technology, the achievements of pedagogical theory and practice, and deepen professional and language training, the academic mobility of teachers and students had become much more active. If in the past, the leader of the internship opportunities provision was Germany, then in the early XX century more frequent had become visits to the United States, especially those of technical specialties. However, humanities scholars (historians, philologists, art historians) and lawyers often preferred Italy as the cradle of European culture and civilization $^{24}$. Some scholars (M. Drahomanov, M. Hrushevskyi, S. Rusova) used high rostrums in Europe to actualize the problems of domination of strict censorship, ban of the native language and alienation of Ukrainians from higher education in the Russian Empire.

Consequently, at the turn of the XIX and XX centuries, a group of nationally conscious intellectuals (M. Halushchynskyi, F. And A. Kolessy, M. Korduba, I. Krypiakevych, T. Lubenets, O. Makovei, Olena Pchilka, S. Siropolko, M. Rudinskyi, S. Rudnytskyi, S. Smal-Stotsky, H. Khotkevych, V. Shcherbakivskyi) saw the People's University as an alternative to the "state" higher schools, based on the principles of nationality and culture, conformity with the needs of an individual and the whole nation ${ }^{25}$. Over time, the idea of a free Ukrainian university matured; a significant contribution to the development and popularization of this idea was made by educators, teachers, artists, public figures: Kh. Alchevska,

\footnotetext{
${ }^{24}$ State Archive of Kharkiv Region. Fund 770, Description 1, Case 99.

${ }^{25}$ Korzh-Usenko, L. (2017). Contra spem spero: self-realization of Ukrainian women in scientific and teaching activities. VII Internationale virtyelle Konferenz der Ukrainistik. Dialog der Sprachen - Dialog der Kulturen. Die Ukraine aus globaler Sicht (München, 27. Oktober 30. Oktober 2016), München: Open Publishing LMU, pp. 680-690.
} 
V. Barvinskyi, I. Horbachevskyi, B. Hrinchenko, M. Hrushevskyi, D. Doroshenko, C. Dnistrianskyi, I. Puliui, M. Sumtsov, I. Franko, A. Sheptytsky. The idea was supported by the representatives of the creative intelligentsia: the coryphaeus of Ukrainian music and theater M. Lysenko and M. Kropyvnytskyi, the stars of the world scene S. Krushelnytska and O. Mishuh. A comparative analysis shows that the desire to conceptualize and implement the national model of a free higher school was coherent with world educational processes. The representatives of different nations, subordinate to the Habsburg monarchy, sought to open their own universities: Italians in Trieste, Czechs in Brno, Slovenes in Ljubljana, Ukrainians in Lviv. Although the idea of creating a Ukrainian free university in 1914 was supported by the Austrian authorities, moderate parties, the international community, however, it was perceived by the Russian government as a threat to its own national security, close to the declaration of war $^{26}$.

The evidence of the intensification of higher education development during the period of the Ukrainian national statehood of 1917-1920 is the appearance of about 30 higher schools, despite the world war and the economic crisis. Thus, in 1918 the Ukrainian State Universities were opened in Kiev and Kamianets-Podilsky, the Ukrainian University in Poltava, founded by the Ukrainian Society "Prosvita"; the result of private initiative and support of the government of P. Skoropadsky was the creation of Tavriysky (Simferopol) and Katerynoslav Russian universities. In Tavriiskyi and Kamianets-Podilskyi universities, the traditional 4-department structure was supplemented by the Department of Agronomy, and in the latter, also, by the Theological Department. The innovation in higher school was opening of Ukrainian, Jewish, and Polish chairs. At this time, the members of the state leadership and representatives of the public (D. Bahalii, V. Vernadskyi, M. Vasylenko, I. Hanytskyi, O. Hrushevskyi, D. Doroshenko, P. Zaitsev, B. Kistiakivskyi, O. Muzychenko, I. Ohiienko, H. Pavlutskyi, M. Plevako, S. Rusova, I. Steshenko, M. Sushytskyi) were solidified in the vision of the higher education institutions as "European in form and Ukrainian in spirit" - the lights of national culture and powerful centers of formation of the Ukrainian intelligentsia ${ }^{27}$. Thanks to the actualization of the national educational ideal, Yaroslav the Wise,

${ }^{26}$ Klopova, M. (2012). National movements of the East Slavic population of AustriaHungary through the eyes of Russian observers (late XIX - early XX century). Russians about Ukraine and Ukrainians, pp. 338-362.

${ }^{27}$ Korzh-Usenko, L. (2017). Genesis of conceptual approaches to organization of the educational process in the higher school of Ukraine. Scientific notes. Series: Pedagogical Sciences, vol. 156, 80-86. 
P. Sahaidachnyi, H. Skovoroda, T. Shevchenko, I. Franko, Lesia Ukrainka had become an examples for youth. The diversification of the educational network contributed to opening of about 50 stationary (Rozovik (2002) and several dozen wandering folk universities.

However, during the Soviet period (1920-1990), a radical reorganization of the higher school was carried out on the basis of a break with the previous academic tradition, refusal taking into account positive foreign experience, affirmation of the priority of class values and Marxist-Leninist ideology, unification, centralization, massisation of higher education, approval of the reproductive learning nature.

Postmodern Period of Higher Education in Ukraine (since the 90's of the twentieth century) is determined by the innovative educational paradigm, the rehabilitation of the idea of academic freedom and university autonomy, the desire for integration into the European and world educational space, the combination of national and anthropocentric foundations in the globalization, internationalization and commercialization context.

\section{CONCLUSIONS}

Thus, the conducted research allowed to carry out periodization of the development of higher education in the territory of Ukraine in accordance with changes of dominant educational paradigms and implementation of new models: pre-institutional (III century BC $-\mathrm{XV}$ century), with which the origins and prerequisites of practice origin are connected higher education; pre-classical (XVI - the end of XVIII century), marked by the activity of fraternal schools, Ostroh and Kyiv-Mohyla Academy, created on the model of European universities of the classical type and adapted to the needs of preserving religious and ethnic identity; classical (beginning - the end of XIX century) is characterized by orientation to classical German university in its Austrian variant, combining the elements of unified French model; modernizational (the beginning - the end of the XIX century) is characterized by an orientation of higher school towards the classical German university in combination with the elements of the French model; at the beginning of the twentieth century the modern stage has been launched, aimed at diversifying education and self-realization of the individual; Soviet (1920-1990), which envisaged a radical reorganization of higher education on the basis of affirmation of class values and Marxist-Leninist ideology; postmodern (since the 90's of the twentieth century), which is based on an innovative educational paradigm.

Among the number of factors, which influenced the process of higher education development on the territory of Ukraine, the historical (deep traditions of the functioning of higher-level institutions, the openness of the Ukrainian educational space to the extrapolation of positive foreign 
experience, and the practice of "educational tourism") are distinguished; socio-political (external and internal policy of the state, democratization of society, growth of national consciousness of the population), economic (scientific-technological progress, modernization of the economy, growth of the need for qualified specialists), socio-cultural (activization of private initiative and socio-pedagogical movement, practice of charity and patronage; endeavour of Ukrainian intelligentsia to develop national culture; strict censorship and prohibition of Ukrainian language, literature, schools in the Russian Empire); educational (the genesis of values, the educational ideal and the goal of education, transformation of the mission of the university, the conceptual maturity of different models of higher education, the ideas of reformatory pedagogy and free higher school); scientific (structuring of science, establishment of new methodological approaches, institutionalization of pedagogy as a separate branch of scientific knowledge, integration into the world of scientific space).

\section{SUMMARY}

The study attempted to distinguish the periods of higher school development in Ukraine, starting with the Athenian system of education in the cities-poleis of the Northern Black Sea coast, schools of higher type in Kyivan Rus, brotherhood schools, Ostroh and Kyiv-Mohyla academies up to developing a broad network of universities and other higher education institutions. The factors that determined quantitative and qualitative changes in the higher school were defined. The transformation of models of higher schools, interconnection of academic traditions and innovations, peculiarities of organization of educational content, forms and methods of education in higher education institutions in the territory of Ukraine in the historical retrospective are characterized.

\section{REFERENCES}

1. A History of the University in Europe. Volumme II: Univerities in early modern Europe (1500-1800). Cambridge University Press, 1996.

2. Babishin, S. (1973). School and education of ancient Rus. Kyiv: Higher school.

3. Bovua, D. (2007). Russian government and Polish gentry in Ukraine (1793-1830). Lviv.

4. State Archive of Kharkiv Region. Fund 45, Description 3, Case 3135.

5. State Archive of Kharkiv Region. Fund 770, Description 1, Case 99.

6. Grachotti, S. (1993). The heritage of the Renaissance in the Ukrainian Baroque. Ukrainian Baroque: Materials of the I Congress of the International Association of Ukrainists, (27 August - 3 September 1990 r.), Kyiv, pp. 3-11. 
7. Hrushevskyi, M. (1992). History of Ukraine-Rus: in 11 vol. Vol. 2: XI-XIII, Kyiv: Scientific thought.

8. Kempa, T. (2009). Kostiantyn Vasyl Ostrozkyi: Voievoda of Kyiv and marshals of Volyn land. Khmelnytskyi.

9. Klopova, M. (2012). National movements of the East Slavic population of Austria-Hungary through the eyes of Russian observers (late XIX - early XX century). Russians about Ukraine and Ukrainians, pp. 338-362.

10. Korzh-Usenko, L. (2017). Contra spem spero: self-realization of Ukrainian women in scientific and teaching activities. VII Internationale virtyelle Konferenz der Ukrainistik. Dialog der Sprachen - Dialog der Kulturen. Die Ukraine aus globaler Sicht (München, 27. Oktober - 30. Oktober 2016), München: Open Publishing LMU, pp. 680-690.

11. Korzh-Usenko, L. (2017). Genesis of conceptual approaches to organization of the educational process in the higher school of Ukraine. Scientific notes. Series: Pedagogical Sciences, vol. 156, 80-86.

12. Korzh-Usenko, L., Martinenko, D. (2013). Development of education in Ukraine of the Cossack period: the context of the dialogue of cultures. III Internationale virtyelle Konferenz der Ukrainistik. Dialog der SprachenDialog der Kulturen. Die Ukraine aus globaler Sicht (München, 14 November, 2012), München - Berlin - Washington, D. C., Verland Otto Sagner, pp. 800-816.

13. Litvinov, V. (2000). Renaissance humanism in Ukraine. Ideas of humanism of the Renaissance in the Ukrainian philosophy of the $X V$ - the beginning of the XVII century. Kyiv.

14. Mykytas, V. (1994). Early Ukrainian students and professors. Kyiv: Abris.

15. Nalyvaiko, D. (1993). Ukraine in the reception of Western humanists of the XV-XVII centuries. In O. Mizanich (Ed.), European Renaissance and Ukrainian Literature of XIV-XVIII cen., pp. 3-39. Kyiv.

16. Nudha, H. (1990). On literary paths (research, searches, finds). Kyiv: Dnipro.

17. Nychyk, V. (2002). From the Renaissance Italy to the Reformation Germany. In V. S. Horskyi (Ed.), Religious-Philosophic thought in KyivMohyla Academy: European Context, Kyiv: Academy.

18. Nychyk, V., Litvinov, V., Stratii, Yu. (1991). Humanistic and Reformation Ideas in Ukraine (XVI - early XVII century). Kyiv.

19. Pakhlovska, O. (1990). Ukrainian-Italian literary connections of the $X V$-XX centuries. Kyiv.

20. Pasichnyk, I. (Ed.) (2011). Ostroh Academy of the XVIXVII centuries: Encyclopedia. Ostroh. 
21. Paton, B., Smolii, V. (Eds.) (2003). History of Ukrainian culture: in $5 \mathrm{vol}$. Vol. 3: Ukrainian culture of the second half of XVII-XVIII centuries. Kyiv.

22. Pritsak, O., Sevcenko, I. (Eds.) (1985). The Kiev Mohyla Academy (Commemorating the 350th Anniversary of Its Founding, 1632-1982), Harvard Ukrainian Studies, vol. VIII, n. 1/2, Cambridge, MA.

23. Rozovik, D. (2002). Ukrainian cultural revival during the years of the national-democratic revolution (1917-1920). Kyiv.

24. Skrzhinska, M. (2013). Education in the process of formation of antique states in the territory of Ukraine (VI-IV centuries BC). In V. Smolii (Ed.), Ukraine in Central-Eastern Europe, vol. 12-13, pp. 15-31. Kyiv.

25. Stanislav Orikhovskyi: works (2004). Kyiv: Dnipro.

26. Sichinskyi, V. (1946). Strangers about Ukraine. The choice from the descriptions of travels around Ukraine and other scriptures of strangers about Ukraine for ten centuries. Avgsburg.

27. Yurii Drohobych: prophecies and reflections (2001). Drohobych.

28. Vakarchuk, I. (Ed.) (2011). Encyclopedia. Lviv Ivan Franko National University: in 2 vol. Vol. 1: A-K. Lviv.

29. Visotskyi, S. (1998). Kyiv writing school (to the history of Ukrainian writing). Kyiv.

\section{Information about the author:}

Larysa Korzh-Usenko,

Doctor of Pedagogical Science, Assistant Professor of Chair of Management of Education and Pedagogy of Higher School

Sumy State Pedagogical University named after A. S. Makarenko

87, Romenska str., 40002, Sumy, Ukraine ORCID ID: orcid.org/0000-0001-9538-4147 